\title{
Anthropocene: Governing Climate Change in China and Brazil
}

\author{
Leila da Costa Ferreira*, Marina Martinelli \\ Center for Environment Studies and Research, Campinas State University, Brazil
}

Copyright $(2016$ by authors, all rights reserved. Authors agree that this article remains permanently open access under the terms of the Creative Commons Attribution License 4.0 International License

\begin{abstract}
This article analyzes governmental responses for the climate change challenge in China and Brazil. Both countries have a central role in the climate change debate since they are major greenhouse gases emitters, thus contributing to the aggravation of the problem, each with differentiated participation. At the same time, policy measures aimed at climate issues in these countries may lead to the reconfiguration of international negotiations on the topic. The methodological aspects include three main points of analysis: the trajectory of greenhouse gas emissions in both countries; political and institutional structures mobilized to the climate issue and focusing on mitigation and policy responses related to climate change.
\end{abstract}

Keywords Climate Change, Climate Policy, Mitigation, China, Brazil

\section{Introduction}

Climate change is ongoing and the increase of Earth's surface average temperature is a direct result from human activities, which includes the high emissions of greenhouse gases (GHG) (mainly from burning fossil fuels) as well as natural variations in the global climate system [25, 26]. Although the debate at the international level has focused on setting goals to reduce and stabilize GHG emissions responsible for the worsening of global warming, the carbon dioxide concentration in the atmosphere has reached record numbers in the last 800,000 years, getting to 35 billion tons in 2013 [43].

As a result, the safe operating limits of the climate system have now been exceeded and it is estimated that global warming will rise to an increase 4 to $5^{\circ} \mathrm{C}$ compared to pre-industrial levels, in this century [31, 30, 48, 49, 38, 26]. The transgression of these limits should increase the risk of irreversible climate change, which includes the loss of major ice sheets, accelerated sea level rise and abrupt changes in forest and agricultural systems. The current debate centers on the contribution of human activities to climate change and the speed with which this phenomenon has been observed since industrial revolution as well as the variation in rate of change between different countries [3, 19].

Human activities are also at the center of the scientific debate on the transition to the Anthropocene [12, 52, 53, 60], which brings out the reflection on the influence of these activities on processes that alter the earth system functioning as a whole and therefore, questions the cultural, social and political aspects of societies' development.

One of the biggest challenges involved in the climate issue relies on the development of the foundation of societies specifically in relation to the dependence on GHGs in industrial and agricultural activities for over two hundred years [36]. The production and consumption patterns necessary to reduce emissions as well as adaptation to climate change require radical changes in the modes of current prevailing development.

In terms of climate change responses, it is argued that governments are important stakeholders that play a key role in defining appropriate rules, institutions and modes of governance to address these changes at different levels and scales $[16,17,7,8,14]$. Climate change policy responses may be related to the mitigation of the problem or to adaptation to the impacts brought by changes in the climate system, and these are very recent. Mitigation actions, the focus of analysis in this paper, seek to promote the reduction and stabilization of GHG emissions which include the replacement of fossil fuels with biofuels, energy use from renewable sources, proper management in agriculture and farming, the carbon market, changes in consumption patterns, waste reduction, and energy efficiency $[5,8]$.

In addition to emission reduction costs and political will, there are other factors that affect mitigation policies, such as experts and non-experts relations, risk perception, regulators-industry relations, the power and influence of interest groups, historical culture and self-perception of a nation $[10,58]$. Mitigation actions are directly related to economic development issues since they require changes in 
the industrial society development foundations.

Both China and Brazil have a central role in the debate on climate change since they are major GHG emitters, thus contributing to the aggravation of the problem, each with differentiated participation. At the same time, policy measures aimed at climate issues in these countries may lead to the reconfiguration of international negotiations on the subject [13]. Within this context, this article analyzes governmental responses for the climate change challenge in China and Brazil. This is not a comparative analysis; it seeks to understand how different political processes respond to the climate change challenge.

\section{Methodological Aspects}

The methodological aspects include three main points of analysis: (i) the trajectory of GHG emissions in both countries, based on secondary data; (ii) political and institutional structures mobilized to the climate issue, focusing on mitigation, based on literature review; (iii) policy responses related to climate change, based on the analysis of policies, plans, programs and major projects related to climate change mitigation through government official documents and reports.

The proposed analysis starts in 1992, with the developments of the United Nations Framework Convention on Climate Change (UNFCCC), resulting from the United Nations Conference on Environment and Development, Eco 92, as it establishes the early involvement of China and Brazil in the debate and negotiations on climate change. The analysis has a 20-year horizon, extending to 2012, due to data availability, especially concerning GHG emissions for both countries.

\section{Climate Issues in China}

\subsection{Chinese Greenhouse Gases Emissions}

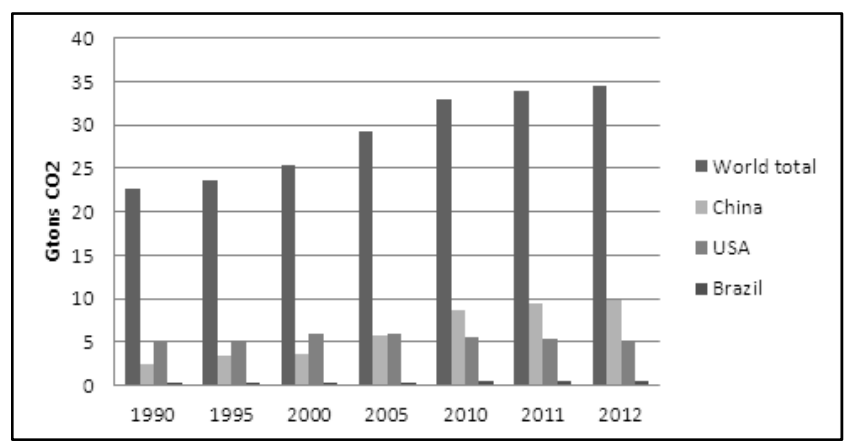

Source: Elaborated by authors, based on Emissions Database for Global Atmospheric Research

(http://edgar.jrc.ec.europa.eu/overview.php?v=CO2ts1990-2013, accessed on $02 / 03 / 16$ ).

Graph 1. $\mathrm{CO}_{2}$ emissions in China (1990-2012)
GHG emissions in China are the largest in the world. From 1990 to 2012, China's emissions have quadrupled, as shown in Graph 1, surpassing the US emissions in 2009. The country's share in total global $\mathrm{CO}_{2}$ emissions was $16.4 \%$ in 2005 , rising to $21 \%$ in 2011 [56].

Climate issues are strongly related to energy issues in China, since the energy sector is the most responsible for Chinese emissions. Coal is the largest energy source, and therefore, responsible for GHG emissions - historically and in future projections. Oil emissions are the second largest and show a growth trend $[34,57]$. The greatest challenge for the country is to change energy consumption patterns and improving energy efficiency.

Even though China made the greatest contribution to the overall increase in GHG emissions in 2012, its growth rate was one of the lowest in the last decade. Furthermore, the energy intensity $\left(\mathrm{CO}_{2}\right.$ emission per unit of gross national product) declined from 2000 to 2012, even with the increase of GDP [22, 57]. The coal share in the energy mix fell from $76 \%$ in 1990 to $68 \%$ in 2005 and the renewable share reached $20 \%$ of the matrix, in 2012 [46]. These data reflect the country's efforts in improving energy intensity and the installation of low carbon power generation, including controversial nuclear power.

\subsection{Political Responses to Climate Change in China}

Based on data analysis, the political and institutional structures and policy responses to climate change in China were divided into two main phases as presented below.

\subsubsection{First Phase: Climate Change Apart from Political Agenda}

This first phase, which extends from 1992 to 2006, is characterized by the development of a series of policies and programs focused on combatting environmental pollution and energy conservation. Climate change mitigation is tangentially treated in this context and appears as a co-benefit of these policy measures.

A consequence of the Climate Convention was the establishment of the National Coordination Committee on Climate Change, in 1998 [45]. However, the creation of this structure was not translated into concrete actions related to the climate issue, and may be perceived as a rhetorical response to the international community.

The Chinese government was increasingly becoming aware of the environmental problems in the country and of the economic and social costs of pollution. The political attention to environmental problems increased with higher impacts of pollution and degradation of natural resources into economy and quality of life. It is estimated that the costs of air and water pollution accounted for almost $6 \%$ of GDP in 2003 [32, 50].

Air pollution and climate change are closely linked in China since the main GHG and major air pollutants come from fossil fuels [27]. Significant changes in the 
environmental pollution approach in general, specifically regarding climate change, marked the beginning of the 1990s in China. These changes could be perceived with the strengthening of environmental laws, programs and institutional capacity by the central government, provinces and municipalities. One important action during this period was the revision of the PRC Jury Code in 1997. This revision added new articles to the code, such as the possibility of penalization through fines for environmental damage in certain activities $[33,50,13]$.

Other instruments focused on the reduction of pollutant emissions in the atmosphere and on the air quality improvement were the Law on Prevention and Control of Air Pollution (revised in 1995), Air Quality National Standard (1996), Emission Standard of Air Pollutants for Thermal Power Plants (2003) and Law on Environmental Impact Assessment (2003) [11, 47, 13].

The Energy Conservation Law, passed in 1998, provides for policy measures related to energy. It is however, considered a very general law and its implementation has not been effective. One important action during this period was the adoption of the Renewable Energy Law of the People's Republic of China, in 2005, which established renewable energy as a priority within Chinese energy strategies [47].

The most important strategy for mitigating climate change was part of the $11^{\text {th }}$ Five-Year Plan (FYP) for National Economic and Social Development (2006-2010), which included an ambitious commitment to reduce $20 \%$ of energy intensity from 2005 to 2010 . It was the first time that climate change was mentioned in the five-year plans. The focus of this action was the top 1,000 energy-consuming industries that accounted for almost half of the industrial consumption in 2004 and included provincial actions. The goal was almost achieved with a $19 \%$ reduction in energy intensity by the end of 2010. Moreover, the mitigation effect of this action resulted in the reduction of 1,510 million tons of $\mathrm{CO}_{2}$ emissions. Even though the achievements of the $11^{\text {th }} \mathrm{FYP}$ were substantial, they were not enough to change the high carbon emissions profile of the Chinese energy mix [47,50, $59,27]$.

At this stage, there were no specific political and institutional structures to address the climate issue, nor specific policy responses to climate change mitigation. However, there were a number of policies aimed at energy conservation and air pollution that prevented Chinese GHG emissions to be even higher.

Conciliating climate change interventions with existing development concerns and strategies is a possibility highlighted in climate policy literature. This means that actions related to climate change issues can also be associated with other social, economic and environmental benefits, enabling many of these initiatives to be successful and long-lasting [1, 5, 29, 20, 15].

For instance, mitigation can be integrated within development interests, such as energy security and infrastructure supply. The construction sector initiatives are usually associated with energy saving; energy efficiency programs are linked to financial saving; urban infrastructure actions can bring direct benefits of improved access, price and service. Actions in the transport sector can reduce traffic congestion and air pollution. Carbon sequestration programs such as planting trees in cities also result in the beautification of urban areas. Mitigation as a co-benefit of pollution reduction policies and energy conservation policies in China is an issue to be explored in future researches.

\subsubsection{Second Phase: Climate Change Agenda Setting}

This phase, from 2007 to 2012, is marked by the establishment of specific structures related to climate change, including government agencies; accountability systems aimed at carbon intensity reduction; climate change studies; specific legislation and strengthening governance systems and mechanisms to deal with this challenge.

One of the most important strategies was the first National Climate Change Program, in 2007. As a result, the National Leading Group to Address Climate Change (NLGACC) was established, comprised of representatives from 20 ministries and government departments and responsible for coordinating climate policy in the various involved sectors. The program includes as climate policy aspects the development of low carbon and renewable energy; planting trees; family planning and the one-child policy.

The importance of the program was in setting the following goals by 2010: $20 \%$ reduction in energy consumption per unit of GDP; $10 \%$ renewable energy in the energy mix (compared to 3\% in 2003) and $20 \%$ forest cover for the country. The Ministry of Science and Technology admitted the difficulty to reverse the increasing trend of energy consumption and GHG emissions in a short period of time $[37,21]$.

The program impacted the provincial level of government and the autonomous regions with the establishment of institutional arrangements linked to climate change, energy saving and environmental pollution. All levels of government have had to report energy-saving efforts and pollution reduction actions since 2008, which led many Chinese local governments to adopt climate policies [39]. The program assumes the position of not taking actions that undermine the country's economic growth, as it argues that developed countries are primarily responsible for GHG emissions reduction which is necessary to prevent global warming.

The central actor influencing Chinese climate change strategies is the National Development and Reform Commission (NDRC), responsible for economic planning and the formulation and implementation of climate policies through its Department of Climate Change. This Commission absorbed the National Leading Group to Address Climate Change [45, 47, 50].

Despite internal targets set by the program, the country had never made commitments to the international community. This situation changed in 2009 when China 
announced the target of GHG reduction per unit of GDP between $40-45 \%$ by 2020 . Although considered unambitious, this was the first international commitment by the country $[21,50]$.

The establishment of mitigation targets characterizes this stage. The "National GHG Control Work Plan" released in 2011 by NRDC, establishes a $17 \%$ reduction target of $\mathrm{CO}_{2}$ intensity for 2011-2015 [57]. The 12th Five-Year Plan (2011-2015) also established $\mathrm{CO}_{2}$ emissions reduction targets, which were adopted by all provinces (autonomous regions and municipalities).

The climate issue involves all levels of government, which are interconnected effectively turning climate change into a multilevel challenge. In this sense, the subnational (provincial) and local (municipal) government levels play an important role in global climate governance. The nation-state remains a central stakeholder in global governance processes, but the role of subnational and local governments cannot be ignored in contributing to policy responses to climate change $[6,19]$.

This phase also included Clean Development Mechanism (CDM) projects. By 2010, the country hosted 737 projects, most of them in renewable energy, energy efficiency and energy savings [50]. Within this stage, climate change issues gradually shifted from being solely scientific to increasingly become a political and economic issue, since energy production and consumption, already linked to economy and politics, are also linked to climate change. This was perceived with the articulation of several ministries and research institutions in order to systematize concrete proposals for GHG emissions mitigation, mainly focused on the energy issue [37].

The China Meteorological Administration (CMA) is the main scientific body regarding climate change and is also a key player in the formulation of climate-related strategies and in international negotiations. CMA leads the National Executive Group on Climate Change; leads China's activities related to the IPCC; co-chairs the National Climate Committee; hosts the National Panel on Climate Change and is the focal point of China's Committee for the Global Climate Observing System ${ }^{1}$. Through its Climate Change Center, it is responsible for elaborating the National Assessments on Climate Change and GHG annual reports.
CMA and the Chinese Academy of Social Sciences worked together on a simulation laboratory related to climate change and economics, responsible for producing climate change actions reports, such as the Annual Report on Actions to Address Climate Change (2009): Road to Copenhagen and the Annual Report on Actions to Climate Change (2010): Cancun's Challenges and Green Paper on Climate Change China's Actions [47].

The presented data show that the main Chinese strategies for GHG emissions reduction are focused on the energy sector and include energy efficiency, energy conservation, renewable energy, nuclear power, industrial emissions control and carbon sinks [45]. Although the primary motivation of many of these actions is to reduce energy costs and improve energy security [47], emissions mitigation is a co-benefit.

\section{Climate Issues in Brazil}

\subsection{Brazilian Greenhouse Gases Emissions}

The evolution of Brazilian GHG emissions is divided into three phases compared to the dynamics of global emissions. First, between 1990 and 1997, Brazilian emissions grew at a faster pace than global emissions. Second, between 1998 and 2004, emissions have grown at a similar pace of global emissions. Finally, after 2005, Brazilian emissions showed a sharp decline as global emissions continued to grow. Nevertheless, in 2008, Brazilian GHG emissions accounted for $5 \%$ of global emissions, when the country was the $5^{\text {th }}$ largest world emitter [55, 40].

For most of the last twenty years land use change and the forestry sector was largely responsible for Brazilian GHG emissions (see Graph 2). In 2005, this sector accounted for $58 \%$ of national emissions. However, in 2005-2007 and then 2008-2012, emissions from this sector decreased significantly, reaching $15 \%$ of total emissions in 2012. This decrease in emissions was mainly due to the reduction of deforestation in the Amazon since 2004. Nevertheless, emissions from other sectors of activity increased in this period. Energy and agriculture were the ones that had the greatest increase in emissions from 2005 to 2012. 


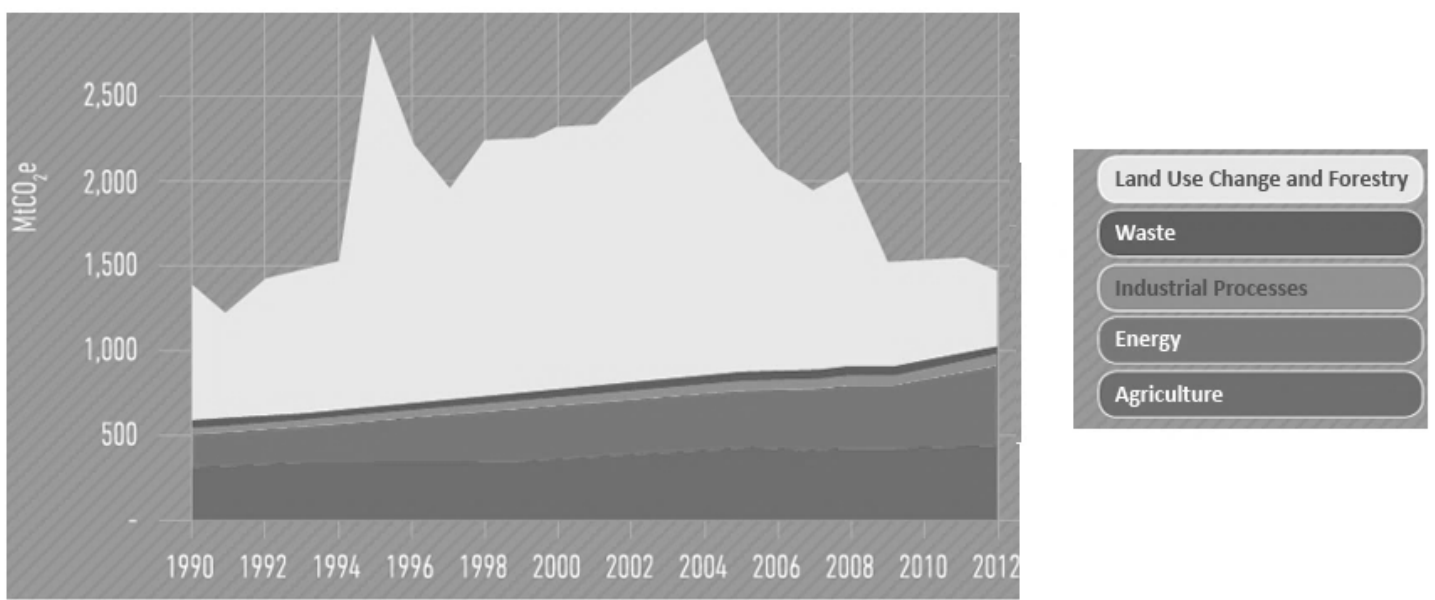

Source: 40 .

Graph 2. Brazilian GHG emissions, by activity sector (1990-2012)

The energy sector stands out due to the rapid growth and high levels of emissions from 1970 to 2013 in comparison to other sectors. During this period, GHG levels in that sector quadrupled, representing 29\% of Brazilian emissions in 2013 [41].

Access to data on the contribution of each sector to national emissions was possible only in 2004, when the first Brazilian inventory of GHG emissions was launched. In this publication emissions referred to the period 1990-1994, that is, with a delay of 10 years regarding the data. The second inventory, published in 2010 showed emissions data for $1990,1994,2000,2005$, still with a delay of five years. The lack of data and the delay in the publications regarding GHG emissions compromise the policy planning, measures and actions to mitigate climate change. Inventories and official estimates are fundamental not only to fulfill the obligations of the country to the UNFCCC, but also to assess the situation of GHG emissions from different sources and the progression of these emissions over time, in order to support public policies aimed at reducing and controlling emissions.

At the same time, civil society has organized and gathered efforts to understand the trajectory of emissions in the country through studies and reports. These initiatives are part of the Climate Observatory, especially through the Estimation System of Greenhouse Gases Emissions.

The analysis of Brazilian GHG emissions trajectory showed that they were significantly reduced for a period, however, there was an $8 \%$ increase in emissions, despite the stagnation of the economy between 2012 and 2013 [51, 41]. It also showed that there has been a change in the profile of GHG emissions in the country, which means that mitigation measures should accompany this change. Besides continuing to focus on the land use change and forestry sector, and hence on deforestation, they must consider energy and agriculture sectors, which have increased their contribution to GHG emissions.

\subsection{Political Responses to Climate Change in Brazil}

Brazilian political responses to climate change were divided into three main stages, as a result of data analysis. Below the main results of each stage are detailed.

\subsubsection{First Phase: Establishment of Political, Institutional and Scientific Structures Related to Climate Change}

This first phase of mobilization for the climate issue, from 1992 to 2002, is marked by the establishment of political, institutional and scientific structures engaged with the issue. Because of this, few actions are highlighted in this initial stage when the issue enters the national political agenda. It is a moment of articulation between international and national negotiation level, among institutions and stakeholders and of political and scientific needs identification.

The first internal response to the Climate Convention took place with the creation of a governmental structure, the Inter Ministerial Committee for Sustainable Development. The first political-scientific mobilizations on climate change was realized with the implementation of the Center for Weather Forecasting and Climate Studies, under the National Institute for Space Research, improving weather and climate modeling systems in Brazil [2].

After that, it was established a more specific framework related to the climate issue, the Inter Ministerial Commission on Global Climate Change, under the Ministry of Science Technology and Innovation, in 1999. The relevance of this commission resided in the articulation of government actions under the Climate Convention, with the participation of several ministries involved in the issue, and in issuing feedbacks on eligible projects for the Clean Development Mechanism (CDM).

The articulation of non-governmental actors around the climate issue came in 2000 with the Brazilian Forum of Climate Change (BFCC). Its main objective was to assist the federal government in the incorporation of climate change issues in public policy by articulating stakeholders from several ministries and government agencies, representatives of private sector, research institutions and civil society. One 
of the positive effects of the forum was the creation of 14 state forums on climate change, enabling the involvement of other levels of government in the debate. Another relevant mobilization in this regard was the Climate Observatory, established in 2002. It integrates the most important civil society organizations in the discussion of climate change issues within the Brazilian context [2].

This period of political-institutional and scientific structures establishment was strongly influenced by the debate at the international level. These structures were relevant to the construction of climate policy at the national level, as discussed below.

\subsubsection{Second Phase: Development of Political-scientific Agenda Focused on Climate Issues}

The second phase of mobilization for the climate issue extends from 2003 to 2008 and stands out for greater understanding of the issue in the country. It is marked by the development of a political and scientific agenda around the theme and planning of mitigation actions in the country. The construction of this agenda played a key role in preparing the foundation for the national policy on climate change.

During this period the "First Brazilian Inventory of Anthropogenic GHG Emissions" was released in 2004. At the same time, the "National Action Plan to Tackle Climate Change", resulting from BFCC contributions culminated in the establishment of the Inter Ministerial Committee on Climate Change and its executive group in 2007. This group played a significant role in the elaboration of the National Plan on Climate Change, which provided the basis for the national policy on climate change [2].

The generation and dissemination of knowledge focused on the challenges of climate change in Brazil has been enhanced by the Brazilian Network for Research on Global Climate Change (CLIMATE Network), in 2007. Another important scientific mobilization was the Centre of Earth System Science in 2008. The center expanded the climate change agenda by integrating global environmental changes and development issues for the country. It was also possible to generate specific scenarios of global environmental change over the next 50 to 100 years and their effects on the national territory $[24,2]$. Until then the scenarios were not specific to Brazil but rather to the South American region. The establishment of the scientific agenda for climate change also included the National Institute of Science and Technology for Climate Change which enabled the formation of an interdisciplinary research network. The articulation and integration of these structures occur through the participation of researchers who comprise the majority of these networks.

The establishment of these political and scientific structures contributed to the foundations of the National Plan on Climate Change in 2008. The relevance of the Plan lies in guidelines for climate change mitigation in sectors such as: energy, transport, construction, industry, agriculture, forestry and solid waste. All actions in progress in these sectors, with GHG emission reduction potential, integrated the plan. However, specific targets to reduce emissions were not part of the established goals.

Climate change mitigation was reinforced with CDM projects during this period. During the $1^{\text {st }}$ commitment period of the Kyoto Protocol, from 2008 to 2012, Brazil received 300 projects. The reduction of GHG emissions associated with these projects is estimated at 351 million tCO2eq, corresponding to $4.8 \%$ of the world total in 2012 [35].

\subsubsection{Third Phase: Establishment of Climate Policy}

The third phase of the climate issue internalization process in Brazil from 2009 to 2012, is marked by the development and adoption of climate policies and the strengthening of the scientific agenda around the theme.

Despite having important scientific structures set out in the second phase, as previously presented, there was a gap in the science-policy interface integration. The Brazilian Panel on Climate Change (BPCC) was launched in 2009 with the aim of filling this gap. It was structured based on the IPCC in order to provide scientific assessments on impacts, vulnerability, adaptation actions, and climate change mitigation. The "First National Assessment Report" of the Panel was published in 2012, during the Rio+20 Conference. The importance of this report lies in the elements that it can provide for the implementation of climate policies in the country, both related to mitigation and adaptation.

Mitigation actions have been reinforced with the regulation of CDM actions through the "Program of Activities under the Clean Development Mechanism". Finally, in the same year, the National Policy on Climate Change (NPCC) was approved. Its approval was strongly related to the international context, prior to the Conference of the Parties under UNFCCC (COP 15) in Copenhagen. This was a turning point in the discussions on climate change in the world, when the theme was in the international political agenda and featured political interest of national governments of many countries. The Brazilian policy had been discussed internally and was based on the National Plan as a result of articulation and mobilization presented in previous sessions. The highlight of this policy was the establishment of voluntary specific targets and deadlines for GHG emissions reduction.

Although the foundations of the policy were already on the national agenda, the establishment of mitigation targets was a result of the private sector and civil society pressure as the core of the government was opposed to assume quantified emissions targets up until July 2009. Therefore, there were no systematic and consistent studies to determine the emissions targets $[18,55,2]$.

An important instrument of NPCC was the National Fund on Climate Change, which uses part of the proceeds from oil exploitation revenue to reinvest in mitigation and adaptation to climate change. The rules for its operation were established in 2011 and in three years of activity US\$ 46 
million were invested in 180 projects. The fund is managed by a steering committee with the participation of representatives from several federal agencies, civil society, states and municipalities.

The NPCC stipulated the preparation of Sectoral Plans, elaborated from 2012 to 2013 . The national policy agenda is focused on the implementation of these sectorial plans.

The presented data show a significant increase in the production and systematization of studies and reports, especially since 2000 , which can assist the preparation and implementation of policies related to the theme and reduce uncertainty related to climate change. Scientific knowledge is fundamental to the development of GHG emission inventories which guide the implementation of plans and reduction targets.

Regarding policy responses related to climate change the results show that climate change mitigation was present in the plans leading up to the national policy. The specific GHG emission reduction targets were a high point of Brazilian policy. Although the country decreased its emissions for a while, the fact that they have been increasing since 2012 represents a new series of challenges that the presented political and institutional structure has to deal with.

\section{Conclusions}

Climate change constitutes an unprecedented challenge to contemporary societies in the transition to the Anthropocene. Responding to this problem, or not doing so, will greatly influence the future life on Earth as climate change mitigation in the coming decades will be crucial to determine the amount of long-term warming and the risks posed by these changes to populations and ecosystems.

Within social and political dimensions of the climate issue, this paper highlighted governments as relevant stakeholders in proposing appropriate forms of climate change governance understanding that they are not the only ones facing this challenge. Emphasizing the importance of this actor does not mean defending a top-down governance system. In this sense, this study analyzed political responses to the climate issue in China and Brazil.

In the Chinese case, various GHG emission reduction targets were presented. In order to meet them, climate strategies are mainly related to energy actions, such as investments in power plants, the largest source of renewable energy in the country, which is also a leader in small scale hydroelectric generation. However, there are projects of major hydroelectric plants such as Three Gorges. Investments in wind and solar power are other strategies. The country also invests in nuclear energy which sets other risks associated with this type of activity.

The reduction of energy intensity in China and stabilization of GHG emissions in 2014 [23] suggest that there has been some progress in meeting the climate targets. This stabilization is especially due to energy generation from renewable sources such as hydro, solar and wind. However, the country remains focused on economic growth and coal continues to dominate the energy mix.

In Brazil, the results showed the participation of non-governmental actors in data elaboration and systematization regarding GHG emissions and in developing mitigation policy strategies to climate change. The significant production and systematization of scientific studies on the subject in the country were highlighted as instruments that can support policy responses to climate change.

Nevertheless, a fourth phase of political and institutional actions to climate change in Brazil begins with some concern regarding GHG emissions, which have been increasing since 2012. If no additional mitigation measures involving other sectors of activity are taken, Brazilian GHG emissions may raise after 2020 [44]. It is possible that the energy sector emissions become the largest by 2050 .

Concurrently, within the national development plan, the country has invested in the oil and gas industry, confronting global discussions on low carbon development. There are few studies on the scenarios of future GHG emissions with the exploration of the Brazilian pre salt oil. There are however decreased chances of oil demand, especially by the transport sector through regulations on fuel efficiency, developing alternative cleaner energy sources and especially reducing the private use of motor vehicles with improved public transportation. In addition, the potential for renewable energy such as wind, solar and biomass is large in the country [44]. Thus, the challenge for climate change mitigation in Brazil is to reconcile the advances in the energy sector and GHG emissions reduction targets set out in the NPCC and to maintain attention on the reduction of deforestation rates.

For scientists, mitigation efforts needed to limit warming to less than $2^{\circ} \mathrm{C}$ above pre-industrial levels are economically viable [15]. The question that remains, however, for both cases presented here is whether the proposed actions and the existing political and institutional structures are sufficient to respond effectively to the magnitude and complexity of the challenge especially in time to prevent irreversible climate change.

In addition, climate policy focused on mitigation must have public involvement, encouraging changes in lifestyle and consumption. The real climate policy is not just about the weather, but about the transformation of basic concepts and institutions established during the development of contemporary society [4]. It is about the transformation of human activities responsible for causing the problem.

In this sense, the transposition of climate issues into the political agenda can be considered as a first response to the challenge [17]. The next move must involve the introduction of this issue in institutions and daily concerns of citizens. And there is certainly much to be done in this direction as well. 


\section{REFERENCES}

[1] Bai, X. 2007. Industrial ecology and the global impacts of cities. Journal of Industrial Ecology 11(2): 1-6.

[2] Barbi, F., G. Mozzer, R. D. Martins, and L. C. Ferreira. 2015. Mudanças climáticas na Rio+20: uma reflexão sobre os 20 anos de negociações climáticas no Brasil. In: Governança Ambiental no Brasil: Entre o Socioambientalismo e a Economia Verde. Eds. F. Castro and C. Futemma. Jundiaí: Pacco Editorial.

[3] Beck, U. 2009. World at risk. Cambridge: Polity Press.

[4] Beck, U. 2010. Climate for Change, or How to Create a Green Modernity? Theory, Culture \& Society, 27(2-3): 254-266.

[5] Betsill, M. M., and H. Bulkeley. 2007. Looking Back and Thinking Ahead: A Decade of Cities and Climate Change Research. Local Governments, 12:5, 447-456.

[6] Bulkeley, H., and M. Betsill. 2003. Cities and Climate Change - Urban Sustainability and Global Environmental Governance. New York: Routledge. 2003.

[7] Bulkeley, H., and K. Kern. 2006. Local Government and the Governing of Climate Change in Germany and the UK. Urban Studies, Vol. 43, No. 12, 2237-2259.

[8] Bulkeley, H., and P. Newell. 2010. Governing Climate Change. New York, Routledge.

[9] Bulkeley H., H. Schroeder, K. Janda, J. Zhao, A. Armstrong, S. Y. Chu, and S. Ghosh. 2009. Cities and Climate Change: The role of institutions, governance and urban planning. World Bank Urban Research Symposium, Marseille.

[10] Burch, S., and J. Robinson. 2007. A framework for explaining the links between capacity and action in response to global climate change. Climate Policy, 7 (4): 304-316.

[11] Chan, C. K., and X. Yao. 2008. Air pollution in mega cities in China. Atmospheric Environment, 1-42.

[12] Crutzen, P. J., and E. F. Stoermer. 2000. The "Anthropocene". Global Change Newsletter'. 41: 17-18.

[13] Ferreira, L. C., and F. Barbi. 2013. Some issues about environmental concerns in Brazil and China (Social justice and transitional societies). In: China \& Brazil: Challenges and opportunities. Eds. L. C. Ferreira, and J. A. G. Albuquerque. São Paulo: Annablume.

[14] Ferreira, L. C., R. D. Martins, F. Barbi, A. M. Urbinatti, F. O. Souza, T. H. N. Andrade, and L. F. Mello. 2012. Risk and Climate Change in Brazilian Coastal Cities. In: Risk and Social Theory in Environmental Management. Eds. T. G. Measham, and S. Lockie. Collingwood: CSIRO.

[15] Field, C., P. Cias, W. Cramer, et al. 2015. Our Common Future under Climate Change. Outcome Statement. UNESCO, Future Earth e ICSU.

[16] Giddens, A. 2000. Runaway world. How Globalization is Reshaping Our Lives. New York: Routledge.

[17] Giddens, A. 2009. The Politics of Climate Change. Cambridge: Polity Press.

[18] Goldemberg, J. 2010. Copenhague: um "post-mortem". Política Externa. v.18, n.4.
[19] Gupta, J. 2007. The multi-level governance challenge of climate change. Journal of Integrative Environmental Sciences, 4:3, 131-137.

[20] Hoornweg, D., L. Sugar, and C. L. T. Gomez. 2011. Cities and greenhouse gas emissions: moving forward. Environment and Urbanization.

[21] Huang, X., D. Zhao, C. G. Brown, and Y. Wu. 2010. Environmental Issues and Policy Priorities in China: A Content Analysis of Government Documents. China: An International Journal, Volume 8, Number 2, pp. 220-246.

[22] IEA - International Energy Agency. 2013. Redrawing the Energy-climate Map. World Energy Outlook Special Report. 2013.

[23] IEA - International Energy Agency. 2015. Global energy-related emissions of carbon dioxide stalled in 2014.

[24] INPE - Instituto Nacional de Pesquisas Espaciais. 2009. Boletim do Grupo de Pesquisa em Mudança Climática. N.7.

[25] IPCC - Intergovernmental Panel on Climate Change. 2007. Climate Change 2007: Synthesis Report. In: Contribution of Working Groups I, II and III to the Fourth Assessment Report of the Intergovernmental Panel on Climate Change. Eds. R.K. Pachauri and A. Reisinger. Cambridge University Press, Cambridge.

[26] IPCC - Intergovernmental Panel on Climate Change. 2013. Climate Change 2013: The Physical Science Basis. Summary for Policymakers.

[27] Jiang, P., Y. Chen, Y. Geng, W. Dong, B. Xue, B. Xu, and W. Li. 2013. Analysis of the co-benefits of climate change mitigation and air pollution reduction in China. Journal of Cleaner Production, 58, pp. 130-137.

[28] Kern, K. and G. Alber. 2008. Governing Climate change in cities: Modes of urban Climate governance in multi-level systems. Competitive Cities and Climate Change, OECD Conference Proceedings, Italy, pp. 171-192.

[29] Kok, M.T.J., and H. C. De Coninck. 2007. Widening the scope of policies to address climate change: directions for mainstreaming. Environmental Science \& Policy. 10, pp. 587-599.

[30] Kriegler, E., J. W. Hall, H. Held, R. Dawson, and H. J. Schellnhuber. 2009. Imprecise probability assessment of tipping points in the climate system. PNAS, doi: 10.1073/pnas.0809117106.

[31] Lenton, T. M., H. Held, E. Kriegler, J. W. Hall, W. Lucht, S. Rahmstorf and H. J. Schellnhuber. 2008. Tipping elements in the Earth's climate system. PNAS. Vol. 105, n. 6.

[32] Macbean, A. 2007. China's Environment: Problems and Policies. The World Economy. Doi: 10.1111/j.1467-9701.20 07.00883.x.

[33] Managi, S. and S. Kaneko. 2010. Chinese Economic Development and Environment. Edward Elgar Publishing Ltd, Cheltenham, UK.

[34] Mckibbin, W. J., P. J. Wilcoxen, and W. T. Woo. China can grow and still help prevent the tragedy of the $\mathrm{CO}_{2}$ commons. 2008. In: China's dilemma: economic growth the environment and climate change. Eds. L. Song and W. T. Woo. ANU E Press and Asia Pacific Press. 
[35] MCTI - Ministério da Ciência, Tecnologia e Inovação. 2014. Status dos projetos no âmbito do Mecanismo de Desenvolvimento Limpo (MDL) no Brasil e no mundo. $1^{\circ}$ Período de compromisso do Protocolo de Quioto (2008-2012).

[36] Meadowcroft, J. 2010. Climate Change Governance. Reference documento for the World Development Report 2010, World Bank.

[37] Most - Ministry of Science and Technology. 2007. China's Scientific \& Technological Actions on Climate Change.

[38] New, M., D. Liverman, H. Schroder, and K. Anderson. 2011. Four degrees and beyond: the potential for a global temperature increase of four degrees and its implications. Philosophical Transactions of the Royal Society A 369, 6-19, doi:10.1098/rsta.2010.0303.

[39] NDRC - The National Development and Reform Commission. The People's Republic of China. China's Policies and Actions for Addressing Climate Change. 2013.

[40] OC - Observatório do Clima. 2014. Análise da evolução das emissões de GEE no Brasil (1990-2012). São Paulo: Observatório do Clima.

[41] OC - Observatório do Clima. 2015. Análise da evolução das emissões de GEE no Brasil (1970-2013) e suas implicações para políticas públicas. São Paulo: Observatório do Clima.

[42] Oliveira, A. P. 2011. A China abraça a causa verde. In: Estratégia. E

[43] REN21 - Renewabl ds. A. Moreira, and P. Ramalho. Instituto Português da Conjuntura Estratégica. Volume XX. Lisboa.

[44] Olivier, J. G. J., G. Janssens-Maenhout, M. Muntean, and J. A. H. W. Peters. 2014. Trends in global $\mathrm{CO}_{2}$ emissions: 2014 Report. PBL Netherlands Environmental Assessment Agency. Institute for Environment and Sustainability (IES) of the European Commission's Joint Research Centre (JRC).

[45] PBMC - Painel Brasileiro de Mudanças Climáticas. 2013. Base Científica das Mudanças Climáticas. $1^{\circ}$. Relatório de Avaliação Nacional. Volume 1.

[46] PRC - The People's Republic of China. 2008. China's Policies and Actions for Addressing Climate Change. Information Office of the State Council of the People's Republic of China. Beijing.

[47] Renewables Energy Policy Network for the 21st century. 2013. Renewables 2013. Global Status Report.

[48] Richerzhagen, C., and I. Scholz. 2008. China's Capacities for Mitigating Climate Change. World Development. Vol. 36, No. 2.

[49] Rockström, J., W. Steffen, K. Noone, Å. Persson, F. S. Chapin,
Iii, E. Lambin, T. M. Lenton, M. Scheffer, C. Folke, H. Schellnhuber, B. Nykvist, C. A. De Wit, T. Hughes, S. Van Der Leeuw, H. Rodhe, S. Sörlin, P. K. Snyder, R. Costanza, U. Svedin, M. Falkenmark, L. Karlberg, R. W. Corell, V. J. Fabry, J. Hansen, B. Walker, D. Liverman, K. Richardson, P. Crutzen, and J. Foley. 2009. Planetary boundaries: exploring the safe operating space for humanity. Nature. Vol. 461.

[50] Scheffer, M., J. Bascompte, W. A. Brock, V. Brovkin, S. R. Carpenter, V. Dakos, H. Held, E. H. Van Nes, M. Rietkerk, and G. Sugihara. 2009. Early-warning signals for critical transitions. Nature. Vol. 461.

[51] Schreurs, M. A. 2011. Climate Change Politics in an Authoritarian State: The Ambivalent Case of China. In: The Oxford Handbook of Climate Change and Society. Eds. J. S. Dryzek, R. B. Norgaard, and D. Schlosberg. Oxford: Oxford University Press.

[52] SEEG - Sistema de Estimativa de Emissão de Gases de Efeito Estufa. 2014. Seminário 2014: Emissões crescem.

[53] Steffen, W., J. Grinevald, J., P. Crutzen, and J. Mcneill. 2011. The Anthropocene: conceptual and historical perspectives. Philosophical Transactions of the Royal Society A, 369: 842-867.

[54] Syvitski, J. P. M. and A. Kettner. 2011. Sediment flux and the Anthropocene. Philosophical Transactions of the Royal Society A, 369:957-975.

[55] Un-Habitat (United Nations Human Settlements Programme). 2011. Cities and climate change: global report on human settlements. Earthscan.

[56] Viola, E. 2010. Impasses e perspectivas da negociação climática global e mudanças na posição brasileira. Breves Cindes 30.

[57] Viola, E., M. Franchini, and T. L. Ribeiro. 2013. Sistema Internacional de Hegemonia Conservadora: Governança Global e Democracia na Era da Crise Climática. 1. ed. São Paulo: Annablume.

[58] Wang, C., J. Lin, W. Cai, and H. Liao. 2014. China's carbon mitigation strategies: Enough? Energy Policy 73, 47-56.

[59] Winkler, H., K. Baumert, O. Blanchard, S. Burch, and J. Robinson. 2007. What factors influence mitigative capacity? Energy Policy 35, 692-703.

[60] Yuan, J, J. Kang, C. Yu, and Z. Hu. 2011. Energy conservation and emissions reduction in China: Progress and prospective. Renewable and Sustainable Energy Reviews. Vol. 15 (9), pp. 4334-4347.

[61] Zalasiewicz, J., M. Williams, A. Haywood, and M. Ellis. 2011. The Anthropocene: a new epoch of geological time? Philosophical Transactions of the Royal Society A, 369: 835-841. 